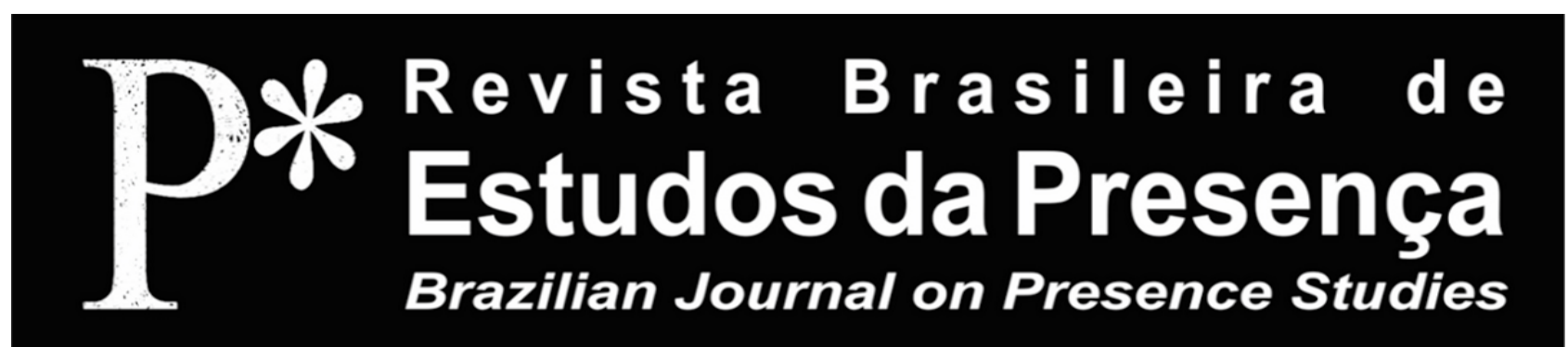

\title{
A literatura que move a obra de Lia Rodri-
}

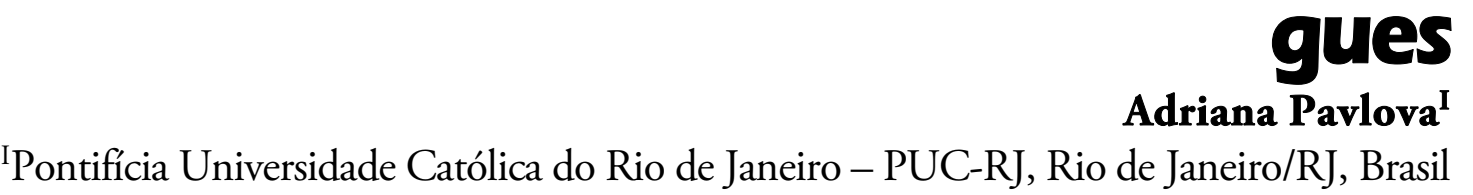

RESUMO - A literatura que move a obra de Lia Rodrigues ${ }^{1}$ - Este artigo apresenta as leituras que moveram o trabalho da coreógrafa Lia Rodrigues (1956), desde os anos 1990, até sua peça de 2016, Para que o céu não caia. O estudo elenca obras de ficção e não ficção, incluindo literatura, filosofia e antropologia, que serviram de dispositivos disparadores para as dramaturgias dos trabalhos, sem, contudo, buscar traduzir a palavra escrita de forma linear ou narrativa em dança. A análise apresenta estas dobras coreográficas, que fogem de uma leitura convencional, para atingir estados corporais nos bailarinos. $\mathrm{O}$ levantamento das leituras é apresentado em sua relaçáo com o repertório da companhia, propondo diálogos de fragmentos dos textos com a dança.

Palavras-chave: Dança. Criaçáo coreográfica. Literatura. Transcriaçáo. Lia Rodrigues.

ABSTRACT - The literature that drives the work of Lia Rodrigues - This article presents the readings that inspired the work of choreographer Lia Rodrigues (1956), starting in the 1990s and ending with her 2016 piece, For the sky not to fall. The study lists works of fiction and non-fiction, including literature, philosophy, and anthropology, which served as triggering devices for the works' dramaturgies, while still not seeking to translate the written word in linear or narrative form into dance. The analysis presents this choreographic unfolding, which eschews a conventional reading, to achieve bodily states in the dancers. The collection of readings is presented in relation to the company's repertoire, proposing dialogues between text fragments and dance.

Keywords: Dance. Choreographic creation. Literature. Transcreation. Lia Rodrigues.

RÉSUMÉ-La littérature qui fait bouger l'œuvre de Lia Rodrigues - Cet article présente les lectures qui ont animé le travail de la chorégraphe Lia Rodrigues (1956), depuis les années 1990, jusqu'à la pièce de 2016, Pour que le ciel ne tombe pas. L'étude énumère des œuvres de fiction et de non-fiction, notamment de littérature, de philosophie et d'anthropologie, qui ont servi de déclencheurs aux dramaturgies des œuvres, sans toutefois chercher à traduire en danse les écrits sous forme linéaire ou narrative. L'analyse présente ces doublages chorégraphiques, qui échappent à une lecture conventionnelle pour atteindre différents états corporels chez les danseurs. Le relevé des lectures est présenté en relation avec le répertoire de la compagnie, proposant des dialogues entre des fragments de textes et la danse.

Mots-clés: Danse. Création chorégraphique. Littérature. Transcréation. Lia Rodrigues. 


\section{Introduçáo}

É impossível dissociar literatura e filosofia da obra poética da coreógrafa Lia Rodrigues (1956). Intelectual curiosa e aprofundada, a artista é uma leitora voraz que usa ficção e não-ficção como dispositivos disparadores das dramaturgias de seus trabalhos, dentro e fora da cena. No alicerce de cada peça criada para a Lia Rodrigues Companhia de Danças ${ }^{2}$, há textos literários, filosóficos e de antropologia, alimentando e provocando o laboratório criativo, para irrigar a invenção de novos mundos. "Eu parto sempre da literatura para o meu trabalho. Preciso ler muito para estar num estado de criação, num estado de poesia" (Rodrigues, 2019), disse a artista, em um depoimento ao jornal Folha de S.Paulo. Numa entrevista de 2020, a coreógrafa acrescentou: "Gosto muito de ler filosofia e ficção. Há livros que descobri serem a ignição para o meu trabalho. [...] A literatura é um grande laboratório a partir do qual fazemos experimentos" (Rodrigues, 2020).

Não se trata de uma tentativa de transcrição ou tradução em dança da palavra escrita ou mesmo de narrativas, como muitos coreógrafos fizeram nos primórdios da dança ou ainda fazem, mas, sim, do uso da literatura e demais obras não ficcionais como fonte de inspiraçáo e de interlocuçáo com o mundo e com a arte. Das muitas leituras solitárias, surgem ideias, imagens, sensaçóes e fabulaçôes que, levadas por Lia à sala de ensaio, são partilhadas com os intérpretes, em um verdadeiro processo coletivo de elaboração. Começam com improvisaçôes e incorporaçôes, metamorfoseando-se, aos poucos, em células ou quadro coreográficos e, mais tarde, na dança propriamente dita. Um processo longo ${ }^{3}$ - para os moldes da arte em tempos neoliberais - de busca de corpos capazes de darem conta da obra em construção.

São dobras e torsões coreográficas que vão muito além das narrativas ou dos textos iniciais, transformando-se em carne, em materialidade, criando um lugar vigoroso de reflexáo e de pensamento, repleto de imagens capazes de sobreviver à efemeridade das artes do corpo. Em outubro de 2015, a coreógrafa me falou sobre sua forma nada engessada de trabalhar com a palavra: "Meu uso dos autores não é o mesmo de alguém que estuda literatura ou filosofia. Uso as sensaçóes que o livro me traz" ${ }^{4}$, me disse. 
No exercício de fabulação-literária-coreográfica que marca a obra de Lia Rodrigues desde 1990, quando sua companhia foi criada, percebo múltiplas estratégias de aproximaçáo dos textos. Às vezes basta um livro para embasar uma ideia, como em Encarnado (2005), cujo ensaio Diante da Dor dos Outros, de Susan Sontag foi usado para promover reflexóes sobre a chegada dos corpos da companhia à favela da Maré. Ou uma simples palavra que se transformou em movimento, como aconteceu com arfar, pinçada de uma crônica de Clarice Lispector para a performance Descoberta do mundo, de 2013, embrião de Pindorama (2013). E muitos livros disparadores de sensaçóes e de novas corporalidades, como Grande sertão: veredas, de Guimarães Rosa, para Pororoca (2007); Saturno nos trópicos: a melancolia europeia chega ao Brasil, de Moacyr Scliar sobre história da melancolia, usado em Piracema (2009); e $A$ queda do céu - Palavras de um xamá yanomami, de Davi Kopenawa e Bruce Albert, e a Há mundo por vir? - Ensaio sobre os medos e os afins, da filósofa Deborah Danowski e do antropólogo Eduardo Viveiros de Castro para chegar à coreografia de Para que o céu náo caia (2016). E, finalmente, livros de cabeceira que funcionam como guias, consultados de tempos em tempos, entre os quais está Macunaima, de Mário de Andrade. Como se vê, na trajetória de Lia Rodrigues, a literatura é o arquivo mais robusto para a composição dos corpos e reflexóes que materializam suas criaçóes e açóes. Esse artigo de cunho historiográfico debruça-se sobre as leituras que moveram o trabalho da coreógrafa, desde a criação da sua companhia, em 1990, até sua obra de 2016, Para que o céu náo caia. O levantamento sistematizado das leituras é apresentado em sua relação com as obras do repertório da companhia, propondo possíveis diálogos de fragmentos dos textos com a dança.

\section{Literatura e dança, contexto histórico}

A ligação entre dança e literatura é histórica e longeva. Já no século 17 - nas origens do que se entende como balé clássico - há notícia de que vários poetas escreveram versos para libretos de balé ${ }^{6}$, como conta o pesquisador Roberto Pereira em seu livro Giselle, o vôo traduzido: da lenda do balé (2003, p. 118), no qual analisa justamente a transformaçáo de uma lenda eslava em dança. Com estreia em 1841, na Ópera de Paris, Giselle é a obra arquetípica do balé romântico, em uma época em que “[...] o escritor era um fazedor de 
libretos, um inventor de argumentos nos quais a escritura coreográfica se atinha mimeticamente apenas à trama narrativa" ", afirma a pesquisadora francesa de dança Alice Godfroy (2015, p. 24).

No Brasil, dois estudos sobre a relaçáo de fonte literária e coreografia chamam a atenção e ambos optam por uma leitura intersemiótica. Em sua já citada pesquisa sobre Giselle, Roberto Pereira mapeia textos sobre a lenda das mulheres mortas antes do casamento, transformadas em fantasmas, que teriam influenciado a concepção do balé dos franceses Jules Perrot e Jean Coralli, com libreto de Théophile Gautier. Mas Pereira vai além, ao penetrar na coreografia propriamente dita. Para ele, no segundo ato - a parte fantasiosa e poética do espetáculo -, a movimentaçáo se descola da lenda para mostrar uma dança que transcende a história, em uma operação que parece antecipar uma relação mais livre que se dá entre coreografia e escritas a partir do século 20, com o início da dança moderna. "A dança está lá, sendo meio e fim. A lenda é tema e álibi”, diz Pereira (2003, p. 141), referindo-se ao segundo ato de Giselle, em que as bailarinas fantasmas chamadas de wilis dançam poeticamente sob a luz da lua.

Em sua tese Da Literatura para a dança: a prosa-poética de Gertrude Stein em tradução intersemiótica (2013), a coreógrafa e pesquisadora Daniella Aguiar apresenta as traduçóes para dança como modos de interpretação e de leitura dos textos literários. Para isso, articula textos e peças de Gertrude Stein com espetáculos de dança, dando especial ênfase à transcriação (conceito do poeta Haroldo de Campos) da percepção de tempo e da construção sintática steineanas transformadas em coreografia. As pesquisadoras de dança Mylla da Costa e Lenira Rengel (2020, p. 637) explicam em outro estudo que a transcriação é um processo que "[...] refere-se a uma perspectiva mais ampliada de tradução - que também seria uma nova criação - envolvendo e agregando as composiçóes das açôes, relacionando o espaçotempo do momento da sua criação".

Tanto o conceito de transcriaçáo como o de tradução criativa - também de Haroldo de Campos pinçado por Aguiar em sua tese - parecem se encaixar nas análises que esse estudo pretende fazer da relação da palavra escrita com a dança de Lia Rodrigues. Para Campos, a tradução criativa é 
preferencialmente orientada pela açáo do fragmento, sendo mais intensiva do que extensiva. Diz "[...] a tradução é um modelo em miniatura, que lança sobre o original uma luz transpassante, capaz de revelar virtualidades do todo numa exponenciação da parte" (Campos apud Aguiar, 2013, p. 170). Muito embora Lia não realize traduçóes propriamente ditas, os usos de textos como dispositivos disparadores de suas danças e de suas açóes políticas se aproximam dos conceitos de transcriação e de tradução criativa, por apresentar em seus trabalhos, dentro e fora da cena, a materialização incorporada de uma infinidade de possibilidades virtuais contidas nos textos originais escolhidos e lidos por ela.

Em uma perspectiva histórica, é com a dança moderna, no início do século 20, que a literatura deixa de ser usada como fonte literal ou narrativa da criação coreográfica. Poesia e textos de ficção transformam-se, assim, em ativadores de "[...] paisagens interiores, de sensaçóes poéticas, implícitas, invisíveis, mas fundamentais, capazes de colocar o corpo em movimento" (Godfroy, 2015, p. 24). São corpos que, para se movimentar, já não precisam do respaldo de histórias ou narrativas lineares, em uma renovaçáo iniciada por duas das pioneiras da dança moderna, Isadora Duncan e Martha Graham. No entanto, paradoxalmente, como lembra Godfroy, a grande maioria dos bailarinos e coreógrafos modernos tende a se afastar da parceria literária, justamente por buscar a autonomia de uma linguagem que só naquele momento consegue se desvencilhar de outras artes, para tornar-se uma arte independente, baseada no movimento, sem necessitar mais de atrelar sua dramaturgia às narrativas ou à música.

Mas o distanciamento náo durou muito. Dança e escrita - em suas diferentes derivaçóes - voltaram a se encontrar com força e diversidade nas últimas décadas do século 20 , dentro do cenário coreográfico contemporâneo, marcado pela transdisciplinaridade. Godfroy (2015, p. 26) alerta para o fato de que hoje o uso do texto não tem mais nenhum destaque excepcional num cenário em que a dança é o operador de transversalidades artísticas e o corpo que dança está em diálogo cênico num mesmo espaço-tempo com música, artes visuais, teatro e literatura. Haveria, assim, segundo a pesquisadora francesa, uma multiplicidade de possibilidades de uso de textos na criaçáo 
coreográfica, tais como suporte para imaginação, fonte temática, dispositivo de escrita e indutor de motricidade.

\section{Mário de Andrade}

Ao olhar retrospectivamente, há, em meio à vasta e diversa biblioteca particular de Lia Rodrigues, livros formadores, fundamentais na construçáo de sua dança, que são raízes robustas de seu pensamento artístico. São livros de cabeceira que ela revisita com frequência. E dentre esses, destacam-se, justamente, três ligados à obra de Mário de Andrade, autor seminal para Lia Rodrigues, referência maior em seu trabalho desde a década de 1990. Macunaima, o herói sem caráter e $O$ Turista Aprendiz, ambos de Mário, e O Tupi e o Alaúde: uma interpretação de Macunaima, de Gilda Melo e Sousa, são livros que acompanham a coreógrafa há muitos anos.

Foi em 1995 que Lia Rodrigues se encontrou com as andanças folclóricas de Mário de Andrade pelo norte e nordeste do Brasil, ao iniciar uma pesquisa sobre parlendas, patrocinada pela extinta Bolsa Vitae de Artes. Lia segurou com força nas mãos de Mário durante cinco anos e, desde entáo, náo o largou mais, como gosta de repetir sempre que tem oportunidade. Já em 1996, estreou Folia 1, completamente tomada pelos relatos poéticos-impressionistas do escritor paulista sobre manifestaçóes artísticas populares. A aproximação do mundo literário de Mário ganharia mais fôlego em 1998, com o evento Caixa de Folia, concebido ao lado da jornalista Anabela Paiva, no Museu da República no Rio, que contou com uma versão revista e ampliada da peça anterior, batizada de Folia 2. Fechando o ciclo formador de uma visualidade de inspiração brasileira, no ano seguinte, a coreógrafa idealizou, em parceria com o Sesc/SP, o projeto Coração dos Outros, Saravá Mário de Andrade, com exposição e circulação de espetáculos em 69 cidades de São Paulo. "Esse projeto me indicou que para ser brasileira, eu deveria dar a mão a Mário de Andrade, no sentido simbólico, é claro. E ele me levou pelo Brasil” (Rodrigues, 2020), disse a coreógrafa. Em 2012, Lia escolhera três livros para comentar em um episódio do programa de televisão Livros que amei, e $O$ Turista Aprendiz foi um dos títulos selecionados, como ela explicou à época: 
Comecei a ler sobre folclore, e é claro que eu caí no Mário de Andrade. E eu não conhecia essa faceta do Mário de Andrade, eu conhecia o Mário modernista, Macunaíma, e não toda essa contribuição enorme, que viajou pelo Brasil, que conhecia tudo da nossa cultura, que fez o trabalho maravilhoso, que foram as missóes de pesquisa pelo Norte e Nordeste. Eu me identifico muito com isso na minha própria vida, tento fazer isso, não apenas criar o meu trabalho, mas pensar as condiçôes, o que está no entorno. [...] Tem um olhar que me interessa que é o olhar sobre o outro, o diferente. É isso que eu gosto muito no Turista Aprendiz, o olhar do Mário sobre o outro ${ }^{8}$.

O Turista Aprendiz reúne relatos impressionistas de duas expediçóes de Mário de Andrade pelo norte e nordeste do país, com doses de fabulaçáo, humor e poesia, além de olhar acuradíssimo diante dos mundos novos que se descortinavam à sua frente. Primeiro, em 1927, passou três meses na Amazônia, regiáo que já havia inspirado a redação de Macunaíma, àquela época, ainda em fase de ajustes. Ali, segundo contam as pesquisadoras Telê Ancona Lopez e Tatiana Longo Figueiredo (2015), em uma edição primorosa do livro, Mário transformou-se num pesquisador de cirandas e boi-bumbá, registrando melodias, lendas e parlendas, in loco. Assumidamente etnográfica, a viagem seguinte - de novembro de 1928 à fevereiro de 1929 - teve como foco as manifestaçóes de cultura popular do nordeste brasileiro, justamente no período das festas de Natal, Ano Novo e Carnaval. Um projeto que foi sendo registrado pelo escritor enquanto ainda estava em campo, em um diário em formato de folhetim, publicado no Diário Nacional.

Nesses escritos, sobressai o encantamento por um Brasil totalmente novo, inusitado, capaz de mexer com as suas bases identitárias, como ele mesmo reconhece, em um trecho do livro lido por Lia Rodrigues no programa já citado: "Há uma espécie de sensação fincada da insuficiência, da sarapintação, que me estraga todo o europeu cinzento e bem arranjadinho que ainda tenho dentro de mim" (Andrade, 2015, p. 67).

Esse mergulho vertiginoso na obra de Mário diz muito sobre o percurso artístico de Lia Rodrigues a partir de entáo. Folia 1 e 2 exibiram uma influência explícita do escritor modernista, na movimentação, figurinos, objetos cênicos, trilha sonora e até nas parlendas que costuraram as obras, como se, para a coreógrafa, naquele momento, fosse necessário lançar mão de uma 
brasilidade escancarada, sem nuances. Em sua crítica após a estreia da peça, na Bienal de Dança de Lyon, em 1996, Helena Katz reafirmou o compromisso de Folia com as raízes brasileiras.

Poucas vezes se viu um manifesto de brasilidade debaixo da grife de dança moderna, realizado com tamanha sabedoria. Lia náo apenas criou seu melhor trabalho como também uma peça importante para a dança. [...] É genial como Lia conseguiu dar forma coreográfica à estrutura da repetição, sobreposição e separação sobre a qual as parlendas se constroem (Katz, 1996).

\section{Antropofagia}

A relação com a herança do escritor modernista ganhou novos matizes com o passar dos anos. Mário, seu contemporâneo Oswald de Andrade e todo o patrimônio antropofágico dos dois foram essenciais para Lia consolidar questóes que se tornaram centrais em seu projeto político-poético, como a valorizaçáo de outras origens além da origem branca colonizadora, sobretudo o interesse pelos povos originários do Brasil; uma atmosfera onírica, traduzindo-se na sua dança em doses de humor contidas em alguma de suas peças; $\mathrm{e} \mathrm{a}$ abertura do corpo às novas experiências sensoriais, tanto dos bailarinos em cena como dos espectadores de seus trabalhos. A leitura do Manifesto Antropófago, escrito por Oswald em 1928 (mesmo ano da segunda missão de Mário) marcou, por exemplo, a criação de Pindorama. Só me interessa o que não é meu, frase símbolo do manifesto e do pensamento antropófago, poderia ser chave de compreensão da obra Lia Rodrigues, na sua intensa busca pela troca com os outros, pelo reconhecimento de outras origens, de histórias além das suas, ou seja, de uma valorização assumida da alteridade. Uma devoração à la Oswald de livros, de formas artísticas, de linguagens e de temporalidades, mas também de pessoas e histórias. Uma deglutição do que vem de fora, mas também o entendimento do que está por dentro, das nossas vísceras, das nossas próprias origens. Obviamente, o projeto de aproximaçáa do outro, de inspiração antropofágica, sai da teoria e adentra a prática como uma avalanche com a chegada da companhia à Maré. Disse Lia numa entrevista de 2017:

Tem uma expressão de que eu gosto: "a gente tem que outrar". A gente tem que virar o outro. Náo virar o outro totalmente, mas olhar para a diferença e achar uma coisa que às vezes não combina, mas não faz mal, a gente está junto 
mesmo sem combinar. Meu encontro com a Maré é também assim (Veras, 2017).

Aparentemente, Lia comunga de leituras acadêmicas da antropofagia como um movimento em que há uma revisão crítica da noção de identidade fixa, inspirado no canibalismo ritual indígena, cujo objetivo é se ver sob a perspectiva do outro. De fato, outrar-se. Como afirma Tania Rivera, trata-se de um movimento que pressupóe o descentramento na concepçáo de simesmo. "Um modelo de incorporação do outro que duvida da identidade e brinca com as fronteiras entre o eu e o outro, em uma troca constante e constitutiva, em um jogo em que corpo e sujeito se destacam e acoplam em certa mobilidade" (Rivera, 2015, p. 298). Uma devoração crítica, segundo Haroldo de Campos (1981, p. 11), que envolve uma “[...] transculturação; melhor ainda, uma 'transvaloração' [...] capaz tanto de apropriação como de expropriação, desierarquização, desconstrução". Uma chance de olhar para o outro, mas, ao mesmo tempo, de olhar pra si, criando novos e interessantes caminhos de fabulação e imaginação conceitual, nas palavras do antropólogo Eduardo Viveiros de Castro:

O que toda experiência de uma outra cultura nos oferece é a ocasião para se fazer uma experiência sobre nossa própria cultura; muito mais que uma variação imaginária - a introdução de novas variáveis ou conteúdos em nossa imaginação - é a própria forma, melhor dizendo, a estrutura da nossa imaginação conceitual que deve entrar em regime de variaçáo, assumir-se como variante, versão, transformação (Castro, 2018, p. 21).

A proposta da aproximação das diferenças, de identidades outras, que marcavam a chegada à Maré, invadiu o primeiro trabalho concebido pela companhia na favela, Encarnado, que teve como sustentáculo literário o ensaio Diante da dor dos outros, de Sontag. A leitura guiou os primeiros mo-

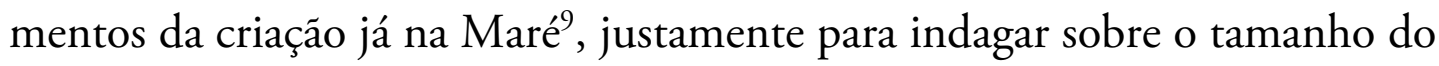
impacto da chegada nos corpos da coreógrafa e dos bailarinos. Um texto bússola que tinha como objetivo oferecer exercícios de imaginação coreográfica capazes de penetrar nos venenos e alimentos surgidos no encontro com aquele terreno desconhecido, repleto de complexidades.

Antes de penetrar em Encarnado, é importante registrar dois outros movimentos de leitura realizados por Lia no fim dos anos 1990 e início de 2000, 
portanto, anteriormente à chegada à Maré. Em 1998, a coreógrafa começou a participar do Grupo de Estudos em Dança do Rio de Janeiro ${ }^{10}$. Dentre os títulos escolhidos nos primeiros anos, destaca-se uma literatura científica de víeis filosófico, escrita por pensadores-cientistas-estudiosos contemporâneos, tratando de assuntos como emoção, cognição, teoria da evolução, arte e ciência $^{11}$. Reflexóes que, ao meu ver, acabaram por impactar os corpos apresentados em Aquilo de que somos feitos, obra de 2000, marcada por uma série de transformaçóes estéticas e políticas do trabalho coreográfico de Lia Rodrigues, dentro e fora da cena. $\mathrm{O}$ ingresso custava $\mathrm{R} \$ 1,99$ e, no programa, havia uma lista minuciosa dos gastos da produçáo, tudo com o claro objetivo de levantar a discussão sobre o valor da arte e o seu mercado. Na sala de espetáculos, não havia lugar marcado para os espectadores, que podiam se locomover durante a apresentação e escolher seu ponto de observação, em uma relação nunca explorada, até então, pela companhia. Em algumas cenas, os intérpretes faziam experiências formais com corpos nus - sem nenhum propósito narrativo - e em outras havia um assumido engajamento político como bandeira.

Já para Formas Breves, peça de 2002 da companhia, a leitura de referência foi Seis propostas para o próximo milênio, de Ítalo Calvino, que, de maneira quase inusitada, se juntou ao legado do artista alemão Oskar Schlemmer, um dos fundadores do movimento modernista de design e de arquitetura nascido na escola de Bauhaus, nos anos de 1920. Em comum, diz o programa da peça no site da companhia, "[...] a discussão do homem e seu futuro e a investigação das estruturas por trás da obra artística"12.

\section{Diante da dor dos outros}

O ensaio Diante da dor dos outros, de Sontag, é uma reflexão sobre os possíveis efeitos das imagens de guerra sobre quem as vê longe do campo de batalha. Lia e os bailarinos escolheram a Maré como um campo de batalha artístico e político, um projeto cuja proposta é olhar para o outro, descolonizar corpos, misturar mundos, tecer novos encontros. Existe satisfação em olhar uma imagem cruel sem titubear? Ver uma realidade dolorosa modifica nosso comportamento, ou seja, nos faz pensar sobre o mal ou nos torna 
indiferentes às desumanidades? É possível assimilar o sofrimento dos outros? A quantidade avassaladora de imagens cruéis exibidas pela mídia, no mundo contemporâneo, acaba nos tornando menos sensíveis? Terá o choque um prazo de validade? O choque pode tornar-se familiar? Somos todos cínicos diante da dor dos outros? Essas são algumas das questóes levantadas pelo ensaio de Sontag, que, de diferentes formas, serviram como provocaçóes para o processo de criação da coreógrafa com sua equipe.

Encarnado ${ }^{13}$ trata da dor do outro, das nossas dores, da convivência ou das dificuldades de conviver, de encontrar-se e de desencontrar-se, de corpos expostos ao mundo e às dores do mundo, das imagens violentas, que, ao se tornarem banais, podem, ou náo, nos ferir profundamente e da possível - táo possível - passividade diante das crueldades humanas. Fascina e impacta justamente por tratar de temas cruciais em uma sociedade que às vezes parece estar em pedaços, anestesiada. É cru e, por vezes, tem muita crueldade envolvida. Por isso, assim como as imagens de violência de guerra, tem tanto potencial para mexer com quem assiste, criando conexóes e empatia com o espectador. Eis o que escreve Sontag em um dos trechos de Diante da dor dos outros:

Mostrar um inferno não significa, está claro, dizer-nos algo sobre como retirar as pessoas do inferno, como amainar as chamas do inferno. Contudo, parece constituir um bem em si mesmo reconhecer, ampliar a consciência de quanto sofrimento causado pela crueldade humana existe no mundo que partilhamos com os outros (Sontag, 2003, p. 95).

A leitura de Diante da dor dos outros inspirou a prática da coreógrafa e de bailarinos colecionarem imagens de crimes brutais publicadas no jornal, para serem reencenados na sala de ensaio. Uma delas mostrava um empresário carioca assassinado no centro da cidade, cujo corpo inerte apareceu no jornal no colo de sua mãe, uma senhora idosa, ajoelhada no cháo, aos prantos. A imagem transformou-se em uma cena batizada de Pietà, na qual uma bailarina embala a outra no colo, amamentando-a com um líquido branco (creme de leite), que explode e escorre pelos corpos das duas. Trata-se, assim, de uma dança que captura o momento, apresentando a violência para além da favela. 
São vários os momentos em Encarnado em que os corpos nus estão à mostra, emporcalhados do líquido vermelho sangue (uma mistura feita de ketchup, molho de tomate e tomate pelado), ressaltando tanto a vulnerabilidade do ser humano como seu lado animal. Um bailarino vomita sangue; outro parece defecar sangue; um outro irrompe no ambiente com uma camisa branca respingada de vermelho, como se tivesse segurado alguém sangrando ou até mesmo levado um tiro, corre de um lado para o outro, em desespero, tentando falar algo, mas não consegue dizer nada compreensível; dois bailarinos-cães, movimentando-se de quatro, mordem uma bailarina, arrastada por eles no chão, arrancando com a boca e com muita fúria suas roupas e vísceras - são, na verdade, pedaços de estopa encharcados de líquido vermelho que já estão nas bocas deles, mas que parecem retirados do corpo dela.

\section{Grande sertáo: veredas}

Pororoca $(2007)^{14}$, peça seguinte à Encarnado, marca uma virada estética na obra de Lia Rodrigues. Com Pororoca, coreógrafa e bailarinos da companhia, naquele momento, inauguram uma nova relação com a literatura, mais afeita aos estados corporais propriamente ditos, mesmo que se sirvam de textos como alicerce poético. Pororoca é uma peça em que os corpos dos intérpretes vibram e, com isso, fazem vibrar os corpos da plateia. Corpos mobilizadores, barulhentos, turbulentos, que explodem em cena, engajando quem está à volta. Um dispositivo disparador mais ligado às sensaçóes, às sensorialidades, capaz de oferecer novas experiências de tempo e de espaço, e que, a partir daí, passa a ser usado como ferramenta criativa, aperfeiçoada de trabalho em trabalho.

Pororoca é uma peça que despedaça de forma ainda mais explosiva as fronteiras entre arte e experiência cotidiana, entre arte e vida, em uma aproximação mais intensa e efetiva do chão da Maré. Uma aproximação que começa de fato por um novo chão, uma nova estrutura de trabalho, em um espaço para coreógrafa e bailarinos chamarem de seu, ao lado da Redes de Desenvolvimento da Maré. Depois de uma busca intensa, Lia Rodrigues encontrou em um galpão fechado na comunidade de Nova Holanda, muito próximo à Avenida Brasil, o lugar aparentemente ideal para abrigar a 
companhia e também muitos outros projetos de arte e cultura da Redes, o Centro de Artes da Maré. E toda a concepção de Pororoca se dá em meio a esse momento de mudança e de muita circulação de intérpretes e coreógrafa pelas ruas da Maré. Uma dança que já nasce contaminada por aquele território, agora muito mais próximo do dia a dia dos corpos dos artistas, que saem da superfície para penetrar mais a fundo naquele chão. Uma dança que captura o momento, o entorno, que articula o contexto em que foi criada, para tratar de um tema que diz respeito a todo ser humano e às subjetividades: estar junto. Um convite a outrar-se. "Pororoca é parecida com as coisas que eu sinto quando ando por aqui na Nova Holanda”, disse a coreógrafa, em uma entrevista a Helena Katz (2009), às vésperas da estreia.

E na busca dos estados corporais nascidos das andanças pela Maré, Lia chegou à leitura de Grande sertão: veredas. Uma leitura capaz de abrir novas percepçóes e entendimentos poéticos. A obra máxima de Guimaráes Rosa ofereceu aberturas para experiências corporais, como a coreógrafa me disse, em uma conversa em 2015:

Uma fala de Antonio Candido sobre Grande sertão me guiou. Ele disse que Tom Jobim pegou o livro e ouviu música. Eu achei essa fala tão extraordinária. No meu caso, eu li dança. Entendi um jeito de estar. Depois da página 60, eu fui jogada num outro universo, parecia que eu estava num outro lugar, vivendo uma experiência física, criada pelas palavras. A Pororoca é uma coisa que acontece dentro, um jeito de se mover. Guimaráes Rosa me ajudou a imaginar, a fazer escolhas ${ }^{15}$.

O crítico Antonio Candido define o texto rosiano de Grande sertão: veredas como uma literatura de imaginaçáo que joga com invençóes na linguagem, na composição, no enredo e na psicologia. O crítico avalia que "[...] há de tudo para quem souber ler" (Candido, 2002, p. 121), como percebeu a coreógrafa em sua assumida opção de transcriaçáo física da obra. E ele diz mais: "Tudo é forte, belo, impecavelmente realizado. Cada um poderá abordá-la a seu gosto, conforme seu ofício; mas em cada aspecto aparecerá o traço fundamental do autor: a absoluta confiança na liberdade de inventar" (2002, p. 121), escreveu Candido. Para Haroldo de Campos, quanto mais complexo o texto, mais liberdade teria o transcriador da obra, como parece ter ocorrido com Lia Rodrigues na leitura de Guimarães Rosa: "Tradução de 
textos criativos será sempre recriação, ou criação paralela autônoma, porém recíproca. Quanto mais inçado de dificuldade esse texto, mais recriável, mais sedutor, enquanto possibilidade aberta à criaçáo" (Campos apud Flores, 2016).

Na entrevista ao programa Livros que amei, em 2012, Lia Rodrigues fala sobre sua maneira de ler O livro do desassossego, de Fernando Pessoa sob o heterônimo de Bernardo Soares, o mesmo gesto de leitura que me parece ter usado em Grande sertão: veredas, apostando em uma relação com a literatura que vai muito além da percepção racional. Ainda criança - a coreógrafa contou no programa -, passava horas conversando com suas irmãs, trocando impressóes sobre o que cada uma fabulava ao ler os mesmos livros. Sobre o Livro do desassossego, Lia disse:

Eu abro, leio, tem aqueles bifóes, aqueles textos gigantescos que não têm ponto, mal vírgula têm. Eu leio como um turbilhão. Eu tenho uma experiência física do livro quando eu leio. Eu entro e começo a ficar assim, me movo diferente, quando eu estou lendo eu me imagino me movendo ${ }^{16}$.

Pororoca começa com os 11 bailarinos em um canto do palco, embolados, segurando objetos variados. Tem cadeira, mesa, roupas, papeláo. De repente, saem jogando tudo para cima e, rapidamente, o chão é tomado pelos objetos largados a esmo. Entre calcinha de mulher, pedaço de caixa e blusa, começa uma dança agitada, com muita esfregação de pele, muito grude de corpos, todos próximos entre eles, muitas vezes de dois em dois. Há muitos barulhos que saem das bocas e do roçar dos corpos, tudo muito orgânico. Se agitam, se roçam, se agarram e num instante param para descansar. De repente, tudo recomeça de novo. Caem no cháo, se atritam no chão, viram mandalas, até pararem novamente. Comem fruta, se lambuzam, tudo sem cerimônia, animalmente. Depois, viram literalmente bichos. Tem gato no cio, cavalo, porco, uivos, latidos. Mais roça-roça, mais disputa, mais embate, mais lábios colados, corpos abraçados, corpos colados, mais brigas, mais amassos. Suor escorrendo, grude de corpo. É físico, é intenso.

Pororoca faz uma convocação inaugural e antropofágica ao espectador. É como se a coreógrafa e os intérpretes dissessem algo como: deixe-se levar pelas sensações nascidas dos encontros dos corpos dos bailarinos, entre nesta 
experiência como você bem entender, sinta, entregue-se, viva novas articulações de tempo e espaço. Aqui, os corpos da cena não pedem passagem, chegam, engajam, sem nenhuma cerimônia. Segundo Lia, trata-se mesmo de uma visita ao universo antropofágico, em uma nova aproximação das ideias de Oswald de Andrade. "Não é pornográfico no sentido do toque e da exibição, mas sim no sentido de você não ter muita certeza de estar num lugar ou noutro e sentir que pode visitar vários lugares diferentes em vários estados diferentes. [...] a gente se vê obrigada a entrar corporalmente na experiência" (Costa, 2010), disse Lia em uma entrevista sobre a obra. Ainda nas palavras dela, é um trabalho disforme, amoral. Antes de mais nada, Pororoca é para ser sentido:

Ele demanda do público uma experiência física e não uma categorização [...] ou um desejo de entendimento. A gente tem de ser livre para receber, que nem uma pororoca passa pela gente. É como quando no carnaval passa um bloco e fica aquela bagunça em que você não sabe bem o que aconteceu mas teve uma experiência física (Costa, 2010).

\section{Saturno nos trópicos}

Esses corpos ruidosos, moventes, mobilizadores de Pororoca ganham uma outra frequência vibratória no trabalho seguinte, Piracema ${ }^{17}$, que, em tupi guarani, é a subida dos peixes contra a corrente para a desova, e que, na minha leitura, funciona como um díptico ao lado da obra anterior. Pororoca e Piracema tratam do estar junto sob ângulos diferentes, intensidades e corporalidades diversas. Parecem responder à famosa pergunta do filósofo Baruch Espinosa: "O que pode um corpo?”, apontando para dois caminhos diferentes, mas complementares. Parece-me que Lia e os demais artistas-criadores se perguntaram: "O que pode um corpo na Maré que também é um corpo do mundo quando encontra outros corpos-mundos?", "Qual é a força política desses corpos, tantos juntos como separados?”. Na primeira resposta, à vista em Pororoca, 11 corpos se roçam, se amam, se odeiam, se encontram, se atritam, se afastam para logo depois se unirem, se agredirem, se acariciarem, virarem bichos, tudo muito junto e muito misturado, em uma explosáo de sentidos. 
Dois anos depois, a mesma pergunta tem uma resposta bem mais árida: são 11 corpos que nunca se encontram, estão no mesmo espaço, mas parecerem olhar para dentro, para suas subjetividades, muitas vezes sem se darem conta do que há à volta. Uma dança solo de 11 corpos. A barulheira que marca Pororoca se torna silêncio - ou quase - em Piracema, que nos seus cerca de 60 minutos de duraçáo só conta com poucos trechos de bossa nova (como A felicidade e Chega de saudade, ambas de Tom Jobim e Vinicius de Moraes), cantados, despretensiosamente, por uma das intérpretes.

Os corpos, que antes estavam em plena loucura do dia a dia de um mundo que não para, agora se dão conta de que não é nada fácil viver sob pressão e que a solidáo pode pesar muito. Impossível, aqui, não atrelar a movimentação crua, o riso nervoso dos bailarinos, seus semblantes carregados, à densidade de um encontro mais profundo (e, claro, muitas vezes doloroso e difícil) com aquele chão de camadas e histórias da Maré. Saturno nos trópicos - A melancolia europeia chega ao Brasil, de Moacyr Scliar, foi a leitura que guiou Lia Rodrigues na busca desse estado corporal mais ensimesmado, retraído, contido de Piracema. "É um trabalho melancólico e o livro trouxe essas sensaçóes. É algo muito brasileiro, uma tristeza, um banzo", me disse a coreógrafa $^{18}$.

Do livro, ela tirou uma frase que evoca sentimentos paradoxais: "Numa terra radiosa vive um povo triste", do Retrato do Brasil: ensaio sobre a tristeza brasileira, de Paulo Prado, citado por Scliar (2003, p. 170). Saturno nos trópicos é um livro-panorama que parte da literatura, artes plásticas, medicina e política para tratar da história da melancolia e seus desdobramentos na cultura brasileira. "A melancolia também pode disseminar-se - uma espécie de contágio psíquico -, dominando o clima de opinião e a conjuntura emocional em um grupo, uma época, um lugar", escreve Scliar (2003, p. 9) logo nas primeiras páginas, em uma comparaçáo da melancolia com a peste. Seu ponto de partida é o livro Anatomia da melancolia, de Robert Burton, lançado em 1621 na Inglaterra. "A melancolia deve ser diferenciada da tristeza, reação até certo ponto normal aos embates da existência. Melancolia não é o banal tédio, que 'nos remete para o real, para o tempo, mas não para o jogo do tempo, como a melancolia'; no tédio, o tempo náo passa, 'roda invariavelmente em 
torno de si mesmo'”, diz Scliar (p. 56, 2003), citando Burton. Em outra menção, dessa vez ao antropólogo Roger Batra, afirma que a “[...] melancolia era uma doença de gente deslocada, de imigrantes. [...] Doença que atacava aqueles que tinham perdido algo e ainda náo haviam encontrado o que buscavam" (Scliar, 2003, p. 105). Seria essa, então, a melancolia que ronda Piracema, a melancolia dos incompletos?

\section{A descoberta do mundo}

Dois anos depois de Piracema, a coreógrafa fechou um ciclo chamado de águas com Pindorama, obra que tem como deflagrador uma palavra retirada de uma crônica de Clarice Lispector, outra autora cara à Lia Rodrigues. Tudo começou com um convite da diretora de teatro Christiane Jatahy para que criasse uma performance a ser apresentada na Casa França-Brasil, no Centro do Rio, em abril de 2013, ou seja, meses antes da estreia de Pindorama, em dezembro do mesmo ano, na França. O único pedido de Jatahy foi que a performance deveria se inspirar em uma crônica de Clarice da coletânea A descoberta do mundo, com textos publicados pela autora no Jornal do Brasil, de 1967 a 1973. Lia leu todo o livro, mas foi uma palavra específica que guiou uma das formas de os bailarinos se moverem tanto na performance como na obra que viria em seguida.

Aceitei o convite, li todo o livro e tinha que escolher uma crônica. De tudo, consegui escolher uma palavra, que é arfar, que achei numa das crônicas, que falava que a Clarice abria uma geladeira e dentro tinha uma tartaruga viva que arfava. E eu lá na minha cabeça imaginei o desenho animado em que a tartaruga tira a casca e fica aquele corpinho assim, imaginei um corpinho em carne viva, dentro de uma geladeira, ocupando uma prateleira inteira e que a carne respirava. Bom, eu achei uma palavra que me motivava. Eu trabalhei com os meninos pensando sobre isso ${ }^{19}$.

Na crônica Máquina escrevendo, de 29 de maio de 1971, Clarice abre o texto falando sobre a liberdade de escrever, sobre o sonho de deixar a página em branco para que cada leitor a enchesse com seus desejos e segue até começar a falar sobre bichos. Em um certo ponto, conta sobre a coisa dentro da geladeira: 
A coisa era branca, muito branca. E, sem cabeça, arfava. Com um pulmáo. Assim: para baixo, para cima, para baixo, para cima. A pessoa fechou depressa a geladeira. E ali ficou perto, de coração batendo. Depois veio a saber do que se tratava. $\mathrm{O}$ dono da casa era perito em caça submarina. E pescara uma tartaruga. E tirara o casco. E pusera a coisa na geladeira para no dia seguinte cozinhá-la e comê-la. Mas, enquanto não era cozida, ela, sem cabeça, nua, arfava. Como um fole (Lispector, 1999, p. 172).

Para a performance, Lia usou um longo túnel de plástico, inspirado na obra de Lygia Clark, por onde os bailarinos nus passavam até saírem arfando, com seus corpos ofegantes, cansados, meio gente, meio coisa, lutando para sobreviverem. Esse corpo exausto, impotente e esgotado surge de novo em Pindorama ${ }^{20}$, como a coreógrafa contou em uma entrevista ao jornal $O$ Globo antes da estreia do trabalho na Maré, no início de 2014.

Em determinado momento ela (Clarice) falava de uma tartaruga arfante. Fiquei com essa imagem na cabeça. Quando comecei a pensar que tipo de corpo a gente queria trabalhar, foi ela que veio. De um corpo entregue, sem vigor, meio à mercê, como um náufrago, sem saída (Rubin, 2014).

Há, em Pindorama, outras leituras disparadoras da coreografia. No momento da criação, Lia voltou-se para textos que se ligavam de alguma forma às origens do Brasil, com o próprio Manifesto Antropófago, de Oswald de Andrade, como já foi dito, mas também Tristes Trópicos, de Claude LéviStrauss, marco dos estudos etnográficos, em que o antropólogo belga relata seus encontros, na década de 1930, com naçôes indígenas brasileiras. Lia leu, ainda, entrevistas do antropólogo Eduardo Viveiros de Castro, autor que reapareceria no esteio intelectual de sua obra seguinte, Para que o céu não caia. Um dado que considero relevante para compreender melhor as leituras da coreógrafa é o fato de que ela fez graduação em História na Universidade de Sáo Paulo, nos anos 1970, com a intençáo de estudar antropologia. No entanto, pouco antes de se formar, envolvida com o movimento estudantil e já dançando profissionalmente, deixou a universidade sem concluir o curso.

Pindorama é terra das palmeiras, mas era como algumas etnias chamavam o Brasil antes da chegada dos portugueses. Eu fiquei pensando muito o que seria um lugar, o Brasil longe, um lugar sonhado, sem construção, como se a gente pegasse uma imagem do Brasil sem nenhuma construção, um lugar sonhado. Sonhei com Pindorama lá atrás e lá na frente, eu acho que ele faz um arco na 
minha mente, um arco do passado com o futuro. Uma espécie de lugar imaginário, um lugar utópico onde esses seres arfam ${ }^{21}$.

\section{A queda do céu}

As leituras que embalaram a criação de Pindorama invadiram, de certa forma, o trabalho seguinte, também guiado pela devoração de pensamentos antropológicos. Em entrevistas desde a estreia de Para que o céu náo caia ${ }^{22}$, em 2016, Lia Rodrigues repetiu que dois livros foram a base para a concepçáo da obra: A queda do céu - Palavras de um xamá yanomami, de Davi Kopenawa e Bruce Albert - que ela leu na versão original, em francês, antes da edição em português, lançada em 2015 - e a Há mundo por vir? - Ensaio sobre os medos e os afins, de Deborah Danowski e Viveiros de Castro, que usam como uma das referências de seu estudo justamente o livro da dupla KopenawaAlbert. A coreógrafa explicou a relação com os dois livros:

Para que o céu não caia não é uma transposição do livro para o palco. Leio, desde muito tempo, artigos e entrevistas de Eduardo Viveiros de Castro. [...] Esses livros e escritos foram o ponto de partida para desenvolvermos essa peça, uma criação coletiva com os 10 artistas bailarinos [...]. Vivemos momentos assustadores, tristes e inquietantes. Fazer uma nova criação requer uma inclinação à esperança, em especial na Maré - esse lugar onde os direitos civis dos moradores são desrespeitados. [...] Foram nove meses de trabalho no Centro de Artes da Maré e nos perguntamos: diante de tantas catástrofes e barbáries, que todos os dias nos assombram e emudecem, neste contexto de drásticas mudanças climáticas que escurecem o futuro, o que nos resta a fazer? Como imaginar formas de continuar e agir? O que cada um de nós pode fazer para, a seu modo, segurar o céu? (Veras, 2017).

E diante de perguntas táo complexas, Lia e bailarinos foram consultar a cosmogonia ameríndia. De novo, mais uma forma de outrar-se. Porta-voz yanomami ${ }^{23}$, liderança desse povo e xamã respeitado, Kopenawa contou com a mediação de seu amigo e antropólogo francês Bruce Albert para compor $A$ queda do céu. O texto final, escrito por Albert, partiu de manuscritos de falas, narrativas e conversas suas com Kopenawa, realizadas entre 1989 até início dos anos 2000. O livro nasce da vontade do xamã de divulgar suas palavras para o mundo, de ser ouvido após séculos e séculos de silenciamento de seu povo. Aprendemos com Kopenawa que os xamás são os seres capazes de segurar a abóboda terrestre. Para os seres da floresta, o céu já teria caído sobre 
os antigos, há muito tempo, e, por isso, temem que a história volte a acontecer se a natureza continuar a ser desrespeitada.

É essa mitologia que Danowski e Viveiros de Castro aprofundam em Há mundo por vir? - Ensaios sobre medos e os fins. Os autores fazem um inventário do estado alarmante em vivemos, da sensação de fim dos tempos que toma a todos, que acaba ganhando forma e intensidade nos passos dos bailarinos da companhia de Lia Rodrigues. A dupla de autores mostra que a partir dos anos 1990, com o consenso científico sobre as transformaçóes do regime termodinâmico do planeta, o fim dos tempos ganha contornos reais. Estaríamos vivendo em uma época chamada de Antropoceno:

[...] é uma época, no sentido geológico do termo, mas ele aponta o fim da "epocalidade" enquanto tal, no que concerne à espécie. Embora tenha começado conosco, muito provavelmente terminará sem nós: o Antropoceno só deverá dar lugar a uma outra época geológica muito depois de termos desaparecido da face da Terra. Nosso presente é o Antropoceno; este é o nosso tempo. Mas este tempo presente vai se revelando um presente sem porvir, um presente passivo, portador de um karma geofísico que está inteiramente fora do nosso alcance anular - o que torna tanto mais urgente e imperativa a tarefa de sua mitigação (Danowski; Castro, 2015, p. 16).

Os autores fazem uma crítica ferrenha ao sistema mundial, tal como faz Kopenawa em seu livro, ao chamar os homens brancos de povo da mercadoria, mostrando a importância desmedida que o Ocidente dá aos bens materiais. A crise ligada ao fim do mundo seria, assim, também a crise do modo de vida criado pelo neoliberalismo. Danowski e Viveiros de Castro (2015, p. 103) lembram que as mitologias ameríndias dão como certo apocalipses periódicos. Citando Kopenawa e Albert, os autores (Kopenawa; Albert, 2015, p. 104) dizem que os yanomami associam as atividades garimpeiras em seus territórios na Amazônia ao enfraquecimento e apodrecimento da camada terrestre e à liberação de eflúvios patogênicos que disseminam doenças e extinçóes biológicas. E fazem um alerta, que, em 2021, parece extremamente profético:

Eles [os yanomami] entendem que a ignorância dos Brancos (apelidados de tatus-gigantes ou queixadas-monstruosos, por sua incessante atividade de escavaçáo e remeximento da terra) relativamente à agência dos espíritos e dos xamãs que sustentam o status quo cosmológico já começou a desencadear uma vingança sobrenatural, que vem provocando secas e inundaçóes em diversos 
pontos do planeta. Em breve, com a morte dos últimos xamás yanomami, os espíritos maléficos tomarão o cosmos, o céu desmoronará e todos seremos aniquilados. Kopenawa ainda admite ser possível que, daqui a muito tempo, outra humanidade sobrevenha, mas os atuais "Brancos comedores de terra" irão desaparecer junto com os indígenas (Danowski; Castro 2015, p. 104).

O chamamento aos corpos que Kopenawa faz, isto é, sua tentativa de sacudir o mundo ocidental com palavras de choque, dá o tom visceral da dança de Para que o céu náo caia. Uma dança transcendente que parece nos carregar para a viagem de sensaçóes vividas por Kopenawa em sua experiência de iniciação como xamá. Movido pelo pó de yãkoana, uma substância alucinógena feita de casca de árvore, soprada por seu sogro, ele cai no sono e inicia uma jornada rumo aos ensinamentos da mata, aos fundamentos ocultos do mundo. Essa iniciação é narrada em pormenores, embalada pelas danças esplêndidas e pelos belos cantos dos povos ancestrais, os espíritos xapiri, que vivem em simbiose com a floresta.

Mesmo se tratando de uma transcriação do livro em dança, é impressionante como as imagens evocadas pelo xamá, em seu relato, surgem de diferentes formas em Para que o céu não caia. São cenas como o ritual dos bailarinos de soprar delicadamente pó de café e farinha em seus próprios rostos ou seus corpos repletos de tinta vermelha, imagens que marcam profundamente a visualidade da obra. Diz o livro assim:

Se quiser, apresente-me suas narinas para que eu lhe dê o sopro de vida dos xapiri. Vou fazê-lo virar espírito mesmo! [...] Então ele começou a soprar grandes quantidades de pó em cada uma das minhas narinas, com um tubo de madeira de palmeirinha horoma. Soprava com força e recomeçou várias vezes (Kopenawa; Albert, 2015, p. 134-135).

Outra parte que encontra grande paralelo em o que se vê na cena de Para que o céu não caia e o relato de Kopenawa é, certamente, aquela relativa às danças dos xapiri, que tem profunda ligaçáo com o momento de coreografia mais visceral do trabalho:

Avançam e recuam devagar, bem alinhadas, batendo os pés no chão em ritmo. São magníficas! Em seguida, os espíritos masculinos se lançam e dançam por sua vez, percorrendo um grande círculo com clamores jubilosos. Os xapiri são grandes dançarinos, e muito divertidos. [...] Porém, apesar de toda a sua 
beleza, a dança de apresentação dos xapiri é também apavorante (Kopenawa; Albert, 2015, p. 151-152).

Para que o céu não caia é uma obra em que o público é recebido já com a dança acontecendo. Ao entrar no espaço cênico, um bailarino está espalhando pó de café nas extremidades do tablado, aguçando o olfato de quem está chegando. Sem lugar fixo ou cadeiras para se sentar, os espectadores ficam à vontade para se moverem como quiserem e onde quiserem, enquanto dez bailarinos nus tomam o fundo da cena, lado a lado, tiram toda a roupa e se besuntam de pó de café por todo o corpo. Coreograficamente, sopram o pó preto em suas máos, que cola em seus rostos como uma máscara.

Lambuzados de café, os bailarinos seguem lentamente em direção ao público para encarar cada membro da plateia com os olhos, criando uma evidente conexão. A partir daí, novos encontros acontecem enquanto os performers vão ganhando outras máscaras, outras cores, outros pós, como o branco da farinha, também colada aos corpos, cada vez mais melados de suor. Em um dado momento, eles colocam panos velhos no rosto e passam a rastejar pelo chão, tal como animais longe de seus bandos ou homens e mulheres jogados pelas ruas, quando lhes falta um teto. Os artistas emitem sons, grunhidos, barulhos esquisitos, que mais uma vez tiram o espectador de sua zona de conforto.

Depois, já besuntados com uma tinta vermelha em algumas partes do corpo, os intérpretes reúnem-se no centro da cena e mostram uma dança intensa, marcada pelo barulho dos pés batendo com força no chão de madeira, em um ritmo constante, enquanto emitem sons diversos com a boca. Ali, a união é sinônimo de potência, mesmo quando um dos bailarinos se afasta para mostrar seu momento solo. Fazem um círculo, póem-se em linha, sempre lado a lado. Uma dança em que o coletivo mostra sua força absurda. Um chamado de resistência e de sobrevivência em um mundo onde está cada vez mais difícil viver. Um céu no chão que termina brilhando com os efeitos do pó de cúrcuma (açafráo da terra) no tablado de madeira. Com sua potência transbordante, Para que o céu não caia é uma forte experiência artística, uma forma contundente de corpos afetarem e serem afetados dentro e fora da cena. 
No texto A literatura como antropologia especulativa, o professor de teoria literária Alexandre Nodari (2015) apresenta o ato de ler ciência e filosofia como uma tentativa de dar consistência, entender ou sustentar o nosso mundo, mas, ao mesmo tempo, de modo distinto, ele afirma que também lançamos mão de literatura e de manifestos políticos justamente para ver que o mundo não seria tấo consistente assim, que é contingente (no sentido de incerto), por isso somos capazes de transformá-lo. Nodari pressupóe que a literatura só se torna experiência de fato quando há o encontro das duas dimensôes possíveis, um entrecruzamento: "[...] fazer o mundo consistir e também desconsisti-lo, dando consistência a outros mundos descobertos" (p. 78). A leitura seria, assim, uma prática ético-política-ecológica. "Ela não se reduz à leitura de textos escritos, isto é, à leitura no sentido estrito mas constituiu uma experiência [grifo do autor] de contato do mundo e suas diferentes intensidades". Seguindo uma prática ético-política-ecológica, Lia Rodrigues nos ensina, com sua dança e com as suas ações nutridas pela literatura, filosofia e antropologia, que há novos mundos possíveis, com novos desenhos de nossos corpos e papéis na vida. Mundos sonháveis dentro e fora da cena, capazes de construir novos corpos sensíveis. E isso é muito.

\section{Notas}

1 Este trabalho é fruto da pesquisa da minha tese de doutorado. Ver Pavlova, 2021.

2 Em 2021, a Lia Rodrigues Companhia de Dança (http://www.liarodrigues.com) completa 31 anos existência. Os últimos 17 anos foram passados no Complexo de Favelas da Maré, na zona periférica do Rio de Janeiro, para onde o grupo se mudou para uma residência em 2004 e, desde então, criou todos seus trabalhos ali, ajudando a fundar o Centro de Artes da Maré (2009) e a Escola Livre de Dança da Maré (2011), ambos frutos da parceria com a Redes de Desenvolvimento da Maré (https://www.redesdamare.org.br/2.

3 Historicamente, as criaçôes da companhia são gestadas durante pelo menos seis meses, mas, em alguns casos, foram cerca de nove meses de concepção e ensaios. 
4 Entrevista presencial à autora realizada em 27 out. 2015, no Centro de Artes da Maré, Rio de Janeiro.

5 "A Maré é um conjunto de 16 favelas onde habitam cerca de 140 mil pessoas, distribuídas ao longo do trecho que vai do Caju até Ramos, pela Avenida Brasil, via de circulação que une o Centro e as áreas periféricas da Zona Oeste da cidade do Rio de Janeiro" (Silva, 2012, p. 61).

6 "Na relação entre literatura e dança, o libreto ocupa importante espaço, pois é ele que garante, no balé, a compreensão da narrativa. $\mathrm{O}$ espectador, no teatro, recebe o programa em que constam não só os créditos do coreógrafo, dos bailarinos e dos músicos, mas também a narrativa da história. Desse modo, ele pode percorrer todo o enredo em alguns minutos de leitura, para entáo reconhecê-lo no placo, traduzido em dança e pantomima” (Pereira, 2003, p. 117-118).

7 “...l'écrivain était un faiseur de livrets, un inventeur d'arguments dans lesquels l'écriture choréphaphique ne retenait, mimétiquement, que la trame narrative", tradução minha.

8 Livros que amei. Programa de televisão, episódio 8, Canal Futura. Direção Suzana Macedo. Rio de Janeiro, 22 mai. 2012. (27m25s).

9 Ver Pavlova, 2015.

$10 \mathrm{O}$ grupo que se reunia semanalmente para ler e estudar junto foi fundado em 1998, pelos críticos Silvia Soter, Roberto Pereira, Beatriz Cerbino, pela coreógrafa e pesquisadora Dani Lima, além de Lia Rodrigues. Os encontros se estenderam até 2006, incluindo outros integrantes, entre eles a autora do artigo.

11 O erro de Decartes, do neurocientista português António Damásio; A perigosa ideia de Darwin, do filósofo e cientista cognitivo estadunidense Daniel Dennett; O rio que saia do Édem, do escritor e biólogo evolutivo britânico Richard Dawkins; e a tese de doutorado da professora e crítica Helena Katz, Um, dois, três: a dança é o pensamento do corpo, são alguns dos livros que foram citados como os mais marcantes por integrantes do Grupo de Estudos em Dança.

12 Disponível em: <http://www.liarodrigues.com/page2/styled-8/styled-19/index.php>. Acesso em: 11 de out 2020. 
13 Um curto trecho deste trabalho está à disposição em: https://www.youtube.com/watch?v=jQ6SY0Ug4H0.

${ }^{14}$ Nesse vídeo, produzido pelo festival Panorama de 2010 sobre Pororoca, há cenas do trabalho e também Lia Rodrigues falando sobre a criação. Disponível em: https://www.youtube.com/watch?v=eMmFvCXdx3g

15 Entrevista feita pela autora, por telefone, em 9 out. 2015.

16 Livros que amei. Programa de televisão, episódio 8, Canal Futura.

17 Cenas de Piracema podem ser vistas neste vídeo curto. Disponível em: https://www.youtube.com/watch?v=GQ77JOXOA64.

18 Entrevista realizada pela autora, pelo telefone, em 9 out. 2015.

19 Depoimento público de Lia Rodrigues, em março de 2014, no Centro de Artes da Maré.

20 Alguns trechos do trabalho disponíveis em: https://www.youtube.com/watch?v=bLHlme_5cZ0.

21 Depoimento de Lia Rodrigues, em março de 2014, no Centro de Artes da Maré.

22 Há trechos do trabalho disponíveis em: https://www.youtube.com/watch?v=QI16RIJV6Qg

23 "No Brasil, o território yanomami, homologado em 1992 com o nome de Terra Indígena yanomami, estende-se por 96.650 quilômetros quadrados no extremo norte da Amazônia, ao longo da fronteira com a Venezuela. Conta com uma população de aproximadamente 21.600 pessoas, repartidas em pouco menos de 260 grupos locais" (Kopenawa; Albert, 2015, p. 44).

\section{Referências}

AGUIAR, Daniella de. Da literatura para a dança: a prosa-poética de Gertrude Stein em tradução intersemiótica. 2013. Tese de Doutorado, Programa de PósGraduação em Letras, Universidade Estadual do Rio de Janeiro. Rio de Janeiro, 2013. 
ANDRADE, Mario. O turista aprendiz. Edição de textos apurado, anotada e acrescida de documentos por Telê Ancona Lopez e Tatiana Longo Figueiredo. Brasília, DF: Iphan, 2015.

ANDRADE, Oswald de. O manifesto antropófago. In: TELES, Gilberto Mendonça. Vanguarda europeia e modernismo brasileiro: apresentação e crítica dos principais manifestos vanguardistas. $3^{\mathrm{a}}$ ed. Petrópolis: Vozes; Brasília: INL, 1976.

CANDIDO, Antonio. O homem dos avessos. In: Tese e antítese, ensaios. T.A Queiroz: São Paulo, 4a edição, 2002.

CASTRO, Eduardo Viveiros. Metafísicas canibais: Elementos para uma antropologia pós-estrutural. São Paulo: Ubu: N-1edições, 2018.

CASTRO, Eduardo Viveiros de e DANOWSKI, Deborah. Há mundo por vir? - Ensaio sobre os medos e os fins. Florianópolis: Cultura e Barbárie Editora, 2015.

CAMPOS, Haroldo de. Da razão antropofágica: a Europa sob o signo da devoração. In: Colóquio Letras, Lisboa, Fundação Calouste Gulbenkian. Lisboa, n. 62, p. 10-25. Julho, 1981. Disponível em: http://coloquio.gulbenkian.pt/bib/sirius.exe/issueContentDisplay?n=62\&p=10\&o=p. Acesso em: 24 nov. 2020.

COSTA, Mylla da; RENGEL, Lenira. Corpos poéticos: o movimento da poesia concreta e o corpo que dança. In: SANTOS, Bárbara; BASTOS, Helena; TOURINHO, Lígia; ROCHA, Lucas (org.). Carnes vivas: dança, corpo e política. Salvador: ANDA, 2020. Coleção Quais danças estarão porvir? Trânsitos, poéticas e políticas do corpo, Volume 9. P. 635-647. E-book.

COSTA, Tiago Bartolomeu. Lia Rodrigues quer-nos aqui dentro. Público, Lisboa, 7 abr. 2010. Ípsilon.

FLORES, Guilherme Gontijo. Da tradução em sua crítica: Haroldo de Campos e Henri Meschonnic. In: Circuladô, Revista de Estética e Literatura do Centro de Referência Haroldo de Campos - Casa das Rosas, ano 4, n. 5, mar. 2016, São Paulo.

GODFROY, Alice. Pourquoi la littérature mobilise-t-elle le corps dansant ? In: NACHTERGAEL, Magali; TOTH, Lucille (org.). Danse contemporaine et littérature: Entre fictions et performances écrites. Pantin: Centre National de la Danse, 2015. P. 23-30. 
KATZ, Helena. Lia Rodrigues faz manifesto à brasilidade. O Estado de S. Paulo, São Paulo, 15 de set. 1996. Caderno 2.

KATZ, Helena. Lia Rodrigues faz Pororoca na França. O Estado de S. Paulo, São Paulo, 17 nov. 2009. Caderno 2.

KOPENAWA, Davi; ALBERT, Bruce. A queda do céu - Palavras de um xamá yanomani. São Paulo: Editora Companhia das Letras, 2015.

LISPECTOR, Clarice. A descoberta do mundo. Rio de Janeiro: Editora Rocco, 1999.

LIVROS que amei. Programa de televisão, episódio 8, Canal Futura. Direção Suzana Macedo. Rio de Janeiro, 22 mai. 2012. (27m25s). Disponível em: https://www.youtube.com/watch?v=JTAJArWfd0E. Primeiro acesso: 21 set. 2016.

NODARI, Alexandre Andre. A literatura como antropologia especulativa. In: Revista da Anpoll, [s. 1.], v. 1, n. 38, p. 75-85, 2015. Disponível em: https://revistadaanpoll.emnuvens.com.br/revista/article/view/836. Acesso em: 30 abr. 2021.

PAVlOVA, Adriana. Dança e Política: Movimentos da Lia Rodrigues Companhia de Danças na Maré. 2015. Dissertação, Programa de Pós-Graduação em Artes da Cena, Universidade Federal do Rio de Janeiro, Rio de Janeiro, 2015. Disponível em: https://www.ppgac-ecoufrj.com.br/uploads/f/s/disserta-adriana-plavova-compressed_A1qL.pdf.

PAVLOVA, Adriana. Em Fúria na Maré. Do diverso ao singular e vice-versa: arquivos que compóem a obra de Lia Rodrigues. 2021. Tese de Doutorado, Programa de Pós-Graduação em Literatura, Cultura e Contemporaneidade, Departamento de Letras, Pontifícia Universidade Católica do Rio de Janeiro. Rio de Janeiro, 2021, 247p. Disponível em: https:/www.maxwell.vrac.pucrio.br/54515/54515.PDF

PEREIRA, Roberto. Giselle, o voo traduzido: da lenda ao balé. Rio de Janeiro: UniverCidade, 2003.

ROSA, João Guimarães. Grande sertão: veredas. Rio de Janeiro: Nova Fronteira, 2015.

RIVERA, Tânia. Por uma ética do estranho. In FABIÃO, Eleonora; LEPECKI, André (org.). Açóes Eleonora Fabiáo. Rio de Janeiro: Tamanduá Arte, 2015. P. 294-306. 
RODRIGUES, Lia. Territórios da Dança. In: Revista E. São Paulo, Sesc, n. 287, setembro 2020. Disponível em: https://www.sescsp.org.br/online/artigo/14681_TERRITORIOS+DA+DANCA. Acesso em: 25 nov. 2020.

RODRIGUES, Lia. Conceição Evaristo foi o farol que me deixou mais sensível. Folha de S. Paulo, São Paulo, 20 out. 2019. Ilustríssima. Disponível em: $<$ https:/www1.folha.uol.com.br/ilustrissima/2019/10/conceicao-evaristo-foi-farol-que-me-deixou-mais-sensivel-diz-lia-rodrigues.shtml. > Acesso em: 12 nov. 2019.

RUBIN, Nani. Os novos mares de Lia Rodrigues. O Globo, Rio de Janeiro, 12 mar. 2014. Segundo Caderno.

SCLIAR, Moacyr. Saturno nos trópicos: a melancolia europeia chega ao Brasil. São Paulo: Companhia das Letras, 2003.

SILVA, Eliana Sousa. Testemunhos da Maré. Rio de Janeiro: Editora Aeroplano, 2012.

SONTAG, Susan. Diante da dor dos outros. São Paulo: Companhia das Letras, 2003.

VERAS, Luciana. O ato artístico não se limita à criação de uma obra. In: Continente, v. 1 jun. 2017. Disponível em: < https://www.revistacontinente.com.br/edicoes/198/ro-ato-artistico-nao-se-limita-a-criacao-de-uma-obrar. Acesso em: 24 jun. 2020.

Adriana Pavlova é doutora em Letras pelo Programa de Pós-Graduação em Literatura, Cultura e Contemporaneidade na PUC-RJ, jornalista, crítica de dança e mestre em Artes da Cena pelo Programa de Pós-Graduação em Artes da Cena da Escola de Comunicação da Universidade Federal do Rio de Janeiro em 2015.

ORCID: https://orcid.org/0000-0002-3559-2291

E-mail: adripavlova@gmail.com

Este texto inédito também se encontra publicado em inglês neste número do periódico. 
Cassia Navas

Gilberto Icle

Henrique Rochelle

Este é um artigo de acesso aberto distribuído sob os termos de uma Licença Creative Commons Atribuição 4.0 Internacional. Disponível em: <http://creativecom mons.org/licenses/by/4.0>. 